\title{
EDITORIAL
}

\section{Hypothesis: Phenol and hydroquinone derived mainly from diet and gastrointestinal flora activity are causal factors in leukemia}

\author{
TA McDonald ${ }^{1}$, NT Holland ${ }^{2}$, C Skibola ${ }^{2}$, P Duramad ${ }^{2}$ and MT Smith ${ }^{2}$ \\ ${ }^{1}$ Office of Environmental Health Hazard Assessment, California Environmental Protection Agency, Oakland; and ${ }^{2}$ Division of Environmental \\ Health Sciences, School of Public Health, University of California, Berkeley, California, USA
}

\begin{abstract}
High background levels of phenol and hydroquinone are present in the blood and urine of virtually all individuals, but vary widely. Phenol and hydroquinone have been strongly implicated in producing leukemia associated with benzene exposure, because they reproduce the hematotoxicity of benzene, cause DNA and chromosomal damage found in leukemia, inhibit topoisomerase II, and alter hematopoiesis and clonal selection. The widely varying background levels of phenol and hydroquinone in control individuals stem mainly from direct dietary ingestion, catabolism of tyrosine and other substrates by gut bacteria, ingestion of arbutin-containing foods, cigarette smoking, and the use of some over-the-counter medicines. We hypothesize that these background sources of phenol and hydroquinone and associated adducts play a causal role in producing some forms of de novo leukemia in the general population. This hypothesis is consistent with recent epidemiological findings associating leukemia with diets rich in meat and protein, the use of antibiotics (which change gastrointestinal flora make-up), lack of breastfeeding, and low activity of $\mathrm{NAD}(\mathrm{P}) \mathrm{H}$ quinone oxidoreductase which detoxifies quinones derived from phenol and hydroquinone and protects against benzene hematotoxicity. An attractive feature of our hypothesis is that it may explain why many people who have no known occupational exposures or significant smoking history develop leukemia. The hypothesis predicts that susceptibility to the disease would be related to diet, medicinal intake, genetics and gut-flora composition. The latter two of these are largely beyond our control, and thus dietary modification and reduced use of medicines that elevate phenol levels may be the best intervention strategies for lowering leukemia risk. Leukemia (2001) 15, 10-20.

Keywords: phenol; hydroquinone; diet; gastrointestinal flora; leuke-
\end{abstract} mia; benzene

\section{Introduction}

The lifetime risk of dying from leukemia in the US is approximately eight in 1000 , or close to $1 \%$, and approximately 30000 new cases of leukemia are diagnosed every year. ${ }^{1}$ The causes of the vast majority of these leukemia cases in the general population are unknown. ${ }^{2}$ Numerous studies have examined possible links to genetics, infectious agents, occupational and environmental exposures to radiation, smoking, pesticides and solvents, and chemotherapy. However, very few have investigated possible dietary links with leukemia, despite the fact that diet is one of the most important causes of cancer. ${ }^{3}$ In this paper, we propose the hypothesis that phenol and

Correspondence: MT Smith, School of Public Health, Division of Environmental Health Sciences, 140 Warren Hall, University of California, Berkeley, California 94720-7360, USA; Fax: 510 642-0427 Disclaimer: The views expressed by Dr McDonald do not necessarily represent those of the Office of Environmental Health Hazard Assessment, the California Environmental Protection Agency or the State of California.

Received 22 May 2000; accepted 12 September 2000 hydroquinone (1,4-dihydroxybenzene), derived mainly from dietary sources, are significant contributing factors in producing de novo leukemia in the general population.

This hypothesis stems from several lines of research that have converged in recent years. First, over the past few decades scientists have conducted intensive investigations to understand the mechanism(s) by which benzene causes leukemia. Although the precise mechanism is not known, evidence continues to mount toward one prevailing theory in which the metabolites, phenol and hydroquinone, are central players. ${ }^{4,5}$ Second, investigators involved in developing biomarkers of exposure or in understanding the pharmacokinetics of benzene, medicinal products and other chemicals in humans have observed high and widely varying background levels of phenol, hydroquinone and other phenolic species in the blood and urine of control individuals (see below). Third, recent studies on genetic susceptibility suggest that quinones and oxidative stress are key risk factors for leukemia. ${ }^{6-9}$ Finally, recent epidemiological studies have identified that consumption of high meat diets, ${ }^{10,11}$ use of antibiotics, ${ }^{12}$ and absence of breastfeeding ${ }^{13-16}$ are risk factors for leukemia. A hypothesis that reconciles all of these different lines of research is that phenolic species derived mainly from dietary sources are involved in generating de novo leukemia in the general population and that exposure to benzene and other environmental leukemogens adds to those rates.

In this paper, we review the evidence that implicates phenol and hydroquinone as risk factors in leukemia, present observations of high background levels of these compounds in human populations, describe the many sources of these phenolic compounds, and discuss additional factors that affect the variability in background levels. A discussion of the predictions and criticisms of the hypothesis follows.

Evidence suggesting that phenol and hydroquinone are causal factors in leukemia

Phenol and hydroquinone play an important role in benzene-induced leukemia

Benzene and ionizing radiation are among the few established environmental causes of leukemia in humans. Although the precise mechanism by which benzene induces leukemia is not known, the prevailing hypothesis is as follows (Figure 1). ${ }^{4,5}$ Benzene is metabolized in the liver primarily by cytochrome P4502E1 (CYP2E1), first to benzene oxide and then to phenol, hydroquinone and other polyphenolic metabolites. These phenolic metabolites can be detoxified by conjugation with sulfate, glutathione or glucuronide. Sulfation may not be a potent detoxification mechanism, because the bone marrow contains high levels of sulfatase that can break down the sulfur 


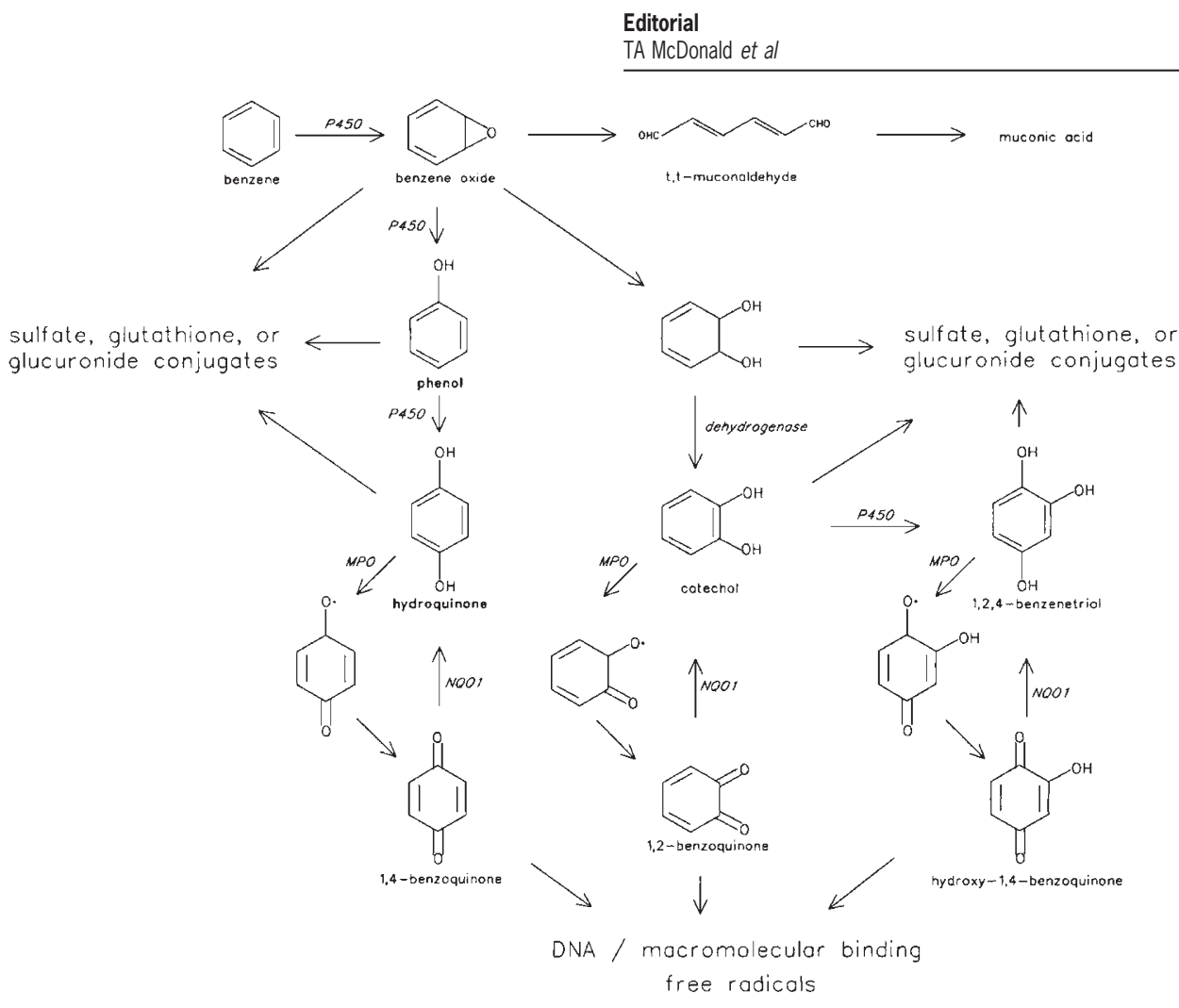

Figure 1 Benzene metabolism and primary carcinogenic pathways. P450, cytochrome P450; MPO, myeloperoxidase; NQO1, NAD(P)H: quinone oxidoreductase.

conjugates to free phenols. ${ }^{17}$ The phenolic metabolites also travel to the marrow where they are converted to highly reactive quinones by peroxidases, such as myeloperoxidase, or through autooxidation. ${ }^{4,5}$ The major defenses against these toxic quinone products include reduction via $\mathrm{NAD}(\mathrm{P}) \mathrm{H}$ : quinone oxidoreductase (NQO1) or conjugation with glutathione. ${ }^{18,19}$ Quinone oxidation products form DNA adducts and induce a wide-range of DNA damage both directly and indirectly (see below). These quinone metabolites also increase oxidative stress $^{20}$ and alter differentiation and cell growth in the myeloid compartment. ${ }^{21-23}$ This combination of genetic and epigenetic effects on bone marrow progenitor cells leads to the production of leukemia in some exposed individuals.

When phenol and hydroquinone are administered together, they reproduce benzene's myelotoxic effects. ${ }^{24,25}$ Phenol and phenol-derived metabolites (eg 4,4 -diphenoquinone) inhibit topoisomerase II and enhance the genotoxic effects of hydroquinone. ${ }^{26}$ Many chemotherapeutic drugs that inhibit topoisomerase II also induce leukemias. ${ }^{27}$ The co-administration of phenol and hydroquinone to mice induces micronuclei and oxidative DNA damage in the bone marrow in a manner similar to benzene. ${ }^{26,28,29}$ Further, combinations of the phenolic metabolites of benzene enhance DNA adduct formation. ${ }^{30,31}$ It has therefore been suggested that all the phenolic metabolites of benzene play a role in benzene-induced toxicity, and that it is the combination that is most toxic. ${ }^{24,32}$

\section{Phenol and hydroquinone produce genetic damage of the type found in leukemia}

Quinones derived from phenol, catechol, hydroquinone and 1,2,4-benzenetriol cause various forms of genetic damage including chromosome breakage and aneuploidy. ${ }^{26,33}$ Aneuploidy is the loss or gain of whole chromosomes and is a frequent clonal aberration in leukemia. Common aneuploidies include trisomy of chromosome 8 and monosomy of chromosomes 5 and 7.34,35 The phenolic metabolites of benzene have been shown to induce trisomy 8 and monosomy 5 and 7 in cultured human cells in vitro, including $\mathrm{CD}_{3}{ }^{+}$progenitor cells. ${ }^{36-38}$ Workers exposed to benzene also have higher levels of these aneuploidies in their peripheral blood. ${ }^{39}$ Through their inhibitory action on topoisomerase II, binding to other DNA-associated proteins and formation of DNA adducts, phenol and hydroquinone cause double-strand breaks and chromosome breakage. ${ }^{40,41}$ This has been shown in vitro to lead to deletions and translocations commonly found in leukemia, including $\operatorname{del}(5 q)$ and $\operatorname{del}(7 q) .{ }^{38}$ Again, workers exposed to benzene have been shown to have higher levels of $\operatorname{del}(5 q)$, $\operatorname{del}(7 q)$ and translocation $(8 ; 21)$ in their blood cells. ${ }^{39,42}$ Mice treated with phenol and hydroquinone also show elevated levels of aneuploidy and chromosome breakage in their bone marrow. ${ }^{26}$

\section{Hydroquinone produces epigenetic changes that increase the risk of developing leukemia}

Other research has focused on the possible epigenetic mechanisms involved in benzene-induced leukemia. Hydroquinone has been shown to alter hematopoietic stem cell proliferation and differentiation in the myeloid compartment. ${ }^{21,22}$ Related effects may include alteration of apoptosis and alteration of clonal expansion of blood progenitor cells (reviewed in Ref. 43). These perturbations may proceed through a variety of means including alteration of inflammatory mediators, growth factors and other cellular messengers. ${ }^{44,45}$ Irons and 
coworkers' demonstrated that treatment of mouse of human marrow progenitor cells of the granulocyte-macrophage lineage with hydroquinone increased the number of colonies dependent on granulocyte-macrophage colony-stimulatingfactor (reviewed in Ref. 21). In theory, this increase provides more targets for the genotoxic effects of phenol, hydroquinone and related species. ${ }^{4}$

\section{NQO1 detoxifies quinones derived from phenol and hydroquinone and protects against leukemia and benzene-induced hematotoxicity}

Additional evidence that the phenolic metabolites of benzene play a central role in benzene-induced leukemogenesis comes from investigations of key enzymes involved in the activation or detoxification of quinones (Figure 1). These enzymes include CYP2E1, which converts benzene to phenol and phenol to hydroquinone, and NQO1, which reduces benzoquinone back to hydroquinone and lowers oxidative stress. ${ }^{5}$ In benzene-exposed workers, a high activity of CYP2E1 and homozygous inheritance of a mutation in the NQO1 gene that eliminates NQO1 activity conferred a 7.6-fold increase in risk of hematotoxicity. ${ }^{6}$ Interestingly, inheritance of the same inactivating C609T mutation in the NQO1 gene also confers increased risk of therapy-related leukemia, ${ }^{7}$ de novo leukemia $^{9}$ and infant leukemia with MLL gene rearrangements. ${ }^{8}$ Recent work from our laboratory suggested that NQO1 protects the marrow against hydroquinone- and 1,2,4-benzenetriol-induced toxicity through an unexpected mechanism, inhibition of high molecular weight DNA adducts. ${ }^{31}$

\section{Phenol and hydroquinone levels in benzene-exposed individuals}

Historically, when occupational exposures to benzene were high (eg 50 p.p.m.), urinary phenol levels were seen as a good biomarker for exposure to benzene. ${ }^{46-48}$ Studies, such as those conducted by Inoue et al, ${ }^{49,50}$ observed a significant correlation between air concentration of benzene in breathing zone and phenol or hydroquinone concentrations in urine (corrected for creatinine and specific gravity) (Figure 2). The authors reported a significant difference between urinary phenol levels in a group exposed to 10 p.p.m. benzene compared to unexposed workers. Similarly, a dose-related increase in urinary phenol levels was observed among groups of Chinese workers exposed to benzene ${ }^{51}$ (Figure 2). Workers exposed to 0, 1 to 31 p.p.m., or 31 p.p.m. exhibited urinary phenol concentrations of 4 to 55 p.p.m., 16 to 487 p.p.m., or 28 to 517 p.p.m., respectively. These findings indicate that high benzene exposure significantly affects the levels of excreted phenol (Figure 2a). However, in these and other studies, urinary phenol and hydroquinone were found to be poor predictors of lower benzene exposures. ${ }^{48-52}$ For example, urinary phenol levels of workers exposed to 1 to 5 p.p.m. benzene were indistinguishable from levels in unexposed individuals. ${ }^{50}$ Likewise, the distributions of urinary hydroquinone levels of unexposed individuals overlapped with urinary levels from female workers exposed to benzene between 9 and 14 p.p.m. ( $7 \mathrm{~h}$, time-weighted average). ${ }^{49}$

\section{Phenol and hydroquinone levels in unexposed individuals}

High background concentrations of phenol, hydroquinone, catechol and 1,2,4-benzenetriol have been measured in the blood, urine and intestines of presumably unexposed humans ${ }^{48-62}$ and in the blood and urine of rodents. ${ }^{63-65}$ Representing measurements of hundreds of individuals in total, these studies showed that mean urinary phenol and hydroquinone levels were about 10 p.p.m. (13 g/mg creatinine) and 4 p.p.m. (5 g/mg creatinine), respectively. The urinary concentrations of phenol and hydroquinone varied widely (ie 5- to 25-fold) within a given population. ${ }^{49-51}$ Some studies have reported differences in phenol levels between sexes, ${ }^{54}$ whereas others have not. ${ }^{48}$ Variability of phenol levels among individuals appears to be greater than the difference among males and females. ${ }^{48}$ Urinary concentrations of phenol have been observed to be approximately 10 -fold higher than concentrations in serum from the same individuals, ${ }^{59}$ which may reflect the rapid removal of phenol from the blood and excretion via urine. Based on mean 24-h urinary levels in control individuals ${ }^{49,50}$ and assuming a daily fluid intake of 2 liters, we estimate that humans produce endogenously or ingest each day roughly $0.2 \mathrm{mg} / \mathrm{kg}$ of phenol, $0.1 \mathrm{mg} / \mathrm{kg}$ hydroquinone, and $0.3 \mathrm{mg} / \mathrm{kg}$ of catechol, with considerable interindividual variability expected.

Interestingly, high background levels of covalent macromolecular adducts of benzoquinone (the reactive metabolite of hydroquinone) were observed in the blood of humans ${ }^{66,67}$ and in the blood and bone marrow of rodents. ${ }^{67-69}$ The adduct levels were equivalent to those resulting from a relatively high exposure to benzene. ${ }^{67,68}$ Several investigators have estimated that exposures to benzene far in excess of the current workplace standard would be required to significantly increase the adduct levels over background levels. ${ }^{65,67,68}$ These observations prompted us to speculate on the pathological consequences that background levels of phenol and hydroquinone may have for the general population.

A number of studies have also assessed phenol levels in patients with different diseases, including colon cancer, familial polyposis, and Crohn's disease. ${ }^{54}$ Patients with diverticular disease or polyposis with ileorectal anastamosis appeared to have elevated urinary phenol levels (about 2-fold) relative to normal individuals. The most noticeable increase in phenol levels was observed among patients with Crohn's disease, which is a common type of inflammatory bowel disease (Figure 2). Phenol levels among Crohn's patients were approximately 4- to 30-fold higher than levels among normal subjects. Interestingly, in agreement with our hypothesis, there are studies suggesting that Crohn's patients have an increased risk of leukemia. ${ }^{70}$

Thus, based on the strong evidence implicating phenol and hydroquinone in benzene-induced leukemia coupled with the observations of high background levels of these compounds in the general population, we hypothesized that these background concentrations and associated adducts may play a causal role in de novo leukemia.

\section{Sources of phenol and hydroquinone in 'unexposed' people}

Our investigation of the available literature has uncovered a surprising number of potential sources of the background levels of phenol and hydroquinone. These include over-the-counter medicines, smoking, numerous foods and beverages, and the catabolism of protein (tyrosine) and other substrates by the gut 
a

Phenol (ppm)



b

Hydroquinone (ug/mg creatinine)



Figure 2 Levels of phenol (a) and hydroquinone (b) in the urine of various groups of individuals. Phenol and hydroquinone levels in the blood and urine are commonly analyzed by gas chromatography in combination with various methods of initial purification and hydrolysis of the specimen. In the earlier studies colorimetric methods of Gibbs or Theis-Benedict were used to quantitate phenol (reviewed in Ref. 48), which were less specific and sensitive compared to gas chromatography. The other important factors affecting reported phenol values are variation in sampling and adjustment for gravity and creatinine. Phenol levels are typically reported as a concentration, mass per mass creatinine, or total mass excreted in $24 \mathrm{~h}$. Data from Refs $47,50,51,54,57,58,75,107,108$.

flora. Below we discuss these sources and also describe additional host and environmental factors that affect the variability of the background levels of the phenolic compounds.

\section{Medicines}

Phenol is used in some relatively unusual medications and treatments, which result in sharp but transitory increases in blood phenol levels. ${ }^{71-74}$ Of more importance to the general population is the use of some over-the-counter medications such as Pepto-Bismol and Chloraseptic lozenges. ${ }^{75}$ In a trial of Pepto-Bismol, urinary phenol concentration increased over 40-fold, reaching a concentration of 260 p.p.m. in a volunteer who ingested $1 \mathrm{oz}$ of Pepto-Bismol every hour for $8 \mathrm{~h}$
(Figure 2). Additional experiments indicated that phenyl salicylate in Pepto-Bismol was responsible for the increase in urinary phenol levels. Fishbeck et $\mathrm{a}^{5}$ also observed increases in phenol levels in human subjects after ingestion of Chloraseptic lozenges. The total urinary phenol rose to a maximum of 270 p.p.m. These studies show that high urinary phenol levels can be achieved without any significant exposure to benzene.

\section{Smoke}

Cigarette and wood smoke contain phenol, catechol, hydroquinone as well as benzene. ${ }^{76-78}$ Amounts received from nonfiltered mainstream cigarette smoke were estimated to be 60 
140 g phenol per cigarette, $140-500$ g catechol per cigarette, and approximately 150-430 g hydroquinone per cigarette. ${ }^{77}$ Haufroid et a ${ }^{99}$ observed statistically significant doserelated increases in the urinary concentrations of phenol, hydroquinone and catechol associated with the number of cigarettes smoked. Cigarette smoking is associated with an approximately $50 \%$ increase in leukemia risk. ${ }^{80,81}$

\section{Diet}

Although the use of cigarettes and certain medicines can result in significantly elevated levels of phenol and hydroquinone in some groups of individuals, diet is a significant source contributing to increased tissue levels of phenol and hydroquinone for all persons. Phenol and hydroquinone are derived from the diet both directly and indirectly. Many common foods and beverages contain phenol and hydroquinone. A major source of phenol stems from catabolism of protein and other compounds by gut bacteria, which appears to depend highly on the metabolic activity of the intestinal bacterial microflora. ${ }^{57,62}$ A potentially significant source of hydroquinone comes from ingestion of foods containing arbutin, a naturally occurring plant product that is converted to hydroquinone by stomach acids. The wide inter-individual variability in urinary levels of phenol noted above may reflect the wide range of direct intake of phenolic-containing foods and differences among individuals in the composition and chemistry of the gut flora.

Phenol, hydroquinone, catechol, and 1,2,4-benzenetriol are found in a wide variety of foods and beverages. As shown in Table 1, fairly high concentrations of phenol, hydroquinone, catechol and benzenetriol are found in coffee. Levels of hydroquinone in some herbal teas were estimated as high as $1 \%$. Lower concentrations of phenol or hydroquinone have been measured in numerous vegetable-based products, alcoholic beverages, dairy products, green and black teas, fruits, roasted nuts, honey, molasses, beef, and spices.

\section{Production of phenol and other phenolics by the gut} flora

Gut microflora may play an important role in the biotransformation of chemical and dietary components into procarcinogenic compounds in the gut. Smith and Macfarlane $^{62}$ have shown that simple phenols are major products of tyrosine metabolism by gut microflora in the distal colon. Tyrosine is an aromatic amino acid that may be ingested through the diet or formed from the essential amino acid, phenylalanine, through an irreversible reaction catalyzed by phenylalanine hydroxylase. Tyrosine and phenylalanine are found in high concentrations in milk, beef and eggs. Phenylalanine is also commonly used as an artificial sweetener in a number of sugarless foods and beverages. Similarly, some commonly occurring plant phenolics are efficiently metabolized by the gut flora of rodents to phenol, catechol and other simple phenols. ${ }^{82,83}$ Escherichia coli can convert glucose to catechol through a minor metabolic pathway; ${ }^{84}$ however, the amount of catechol that might be generated by gut flora from sugars is unknown.

Endogenous bacterial strains that convert tyrosine to phenol include the obligate anaerobes, Bacteroides fragilis, Peptostreptococcus asaccharolyticus, and the facultative anaerobes, Escherichia coli, Proteus sp., Staphylococcus faecalis and Staphylococcus albus (Figure 3). ${ }^{54,62,85}$ Studies of human colonic contents in sudden death victims in the UK showed that anaerobic bacteria outnumber facultative microorganisms in the human gut by two to three orders of magnitude with Bacteroides fragilis being the most numerous ${ }^{86}$ (Figure 3). However, the composition of intestinal bacteria varies considerably among different populations, particularly in Western vs other non-industrialized societies. For example, the microflora from individuals in developed countries have higher levels of Bacteroides, whereas the flora from individuals from undeveloped countries exhibit higher counts of beneficial Lactobacilli. ${ }^{13,14}$ Several proposed reasons for these differences include the sterility of processed western foods, and high meat intake in western diets which results in a substitution of Lactobacilli

Table 1 Dietary sources of phenol, hydroquinone and catechol

\begin{tabular}{|c|c|c|c|c|}
\hline Source & Phenola & Hydroquinone & Catechol & Ref. \\
\hline \multicolumn{5}{|l|}{ Coffee } \\
\hline $\begin{array}{l}\text { Roasted beans } \\
\text { Infusion }\end{array}$ & $1.2-17$ p.p.m. & $\begin{array}{l}\text { 30-40 p.p.m. } \\
0.2 \text { p.p.m. }\end{array}$ & $\begin{array}{l}80-120 \text { p.p.m. } \\
100 \text { p.p.m. }\end{array}$ & $61,99-101$ \\
\hline Alcoholic beverages & & & & \\
\hline $\begin{array}{l}\text { Red wine } \\
\text { Beer } \\
\text { Sherry } \\
\text { Rum }\end{array}$ & $\begin{array}{l}0.02 \text { p.p.m. } \\
\text { detected } \\
0.01 \text { p.p.m. } \\
\text { detected }\end{array}$ & 0.5 p.p.m. & & 61,102 \\
\hline \multicolumn{5}{|l|}{ Teas } \\
\hline $\begin{array}{l}\text { Green or black } \\
\text { Herbal (leaves of blueberry, cranberry, bearberry) }\end{array}$ & detected & $1 \%$ & & 102,103 \\
\hline Dairy products (milk, cheese, butter, whey) & detected & & detected & 102,104 \\
\hline Roasted nuts (almonds, filberts, macadamia, peanuts) & detected & & & 102 \\
\hline Fruits (apples, cherries, cranberries, blueberries, pears, tomatoes) & 0.05 p.p.m. & 0.1 p.p.m. ${ }^{b}$ & & 61,105 \\
\hline $\begin{array}{l}\text { Vegetable products (asparagus, broccoli, dried mushrooms, } \\
\text { hydrolyzed soy protein, onion, rice cereal, roasted barley, roasted } \\
\text { sesame seed, rye crisp bread, popcorn) }\end{array}$ & 0.1 p.p.m. & 0.1 p.p.m. & & 61,102 \\
\hline Miscellaneous (honey, molasses, cocoa, beef, tamarind) & detected & & & 102,106 \\
\hline
\end{tabular}

aCells left blank indicated no data. 'Detected' means the study reported measuring the phenolic species, but did not quantitate the level.

bUp to 110 p.p.m. of hydroquinone has been detected as arbutin in pears (see Table 2). 




Figure 3 Phenol production by gut bacteria. Data compiled from Bone et al, ${ }^{54}$ Smith and MacFarlane, ${ }^{62}$ and Marteau et al. ${ }^{85}$

(which do not produce phenol) with high levels of Clostridia and Bacteroides populations (which produce phenol). ${ }^{13}$

Epidemiological studies have identified several risk factors for leukemia including consumption of high meat diets, ${ }^{10,11}$ use of antibiotics, ${ }^{12}$ and absence of breastfeeding. ${ }^{13-16}$ Each of these risk factors is associated with the potential to alter colonic microflora activity, composition, and resultant phenol production. It is interesting to speculate that phenol production by the gut flora may be a contributing factor in these epidemiological associations.

Individuals consuming high-beef diets have increased populations of phenol-producing anaerobic Bacteroides compared to individuals on vegetarian diets. ${ }^{87,88}$ Comparisons of western and eastern populations indicated that individuals who consume a typical British and American high-meat diet have a higher ratio of anaerobic to aerobic microflora than persons from Japan, Uganda or India, whose diets are largely vegetarian. ${ }^{89}$ These findings were confirmed in a study of volunteers who adopted a strictly vegan diet which led to a decrease in serum and urinary phenol and p-cresol concentrations. ${ }^{59}$ Upon returning to a conventional diet that included the addition of meat and eggs, the volunteers' urinary phenol and p-cresol concentrations correspondingly increased. ${ }^{59}$ Substitution of carbohydrate for protein may not be the only factor responsible for the reduction in phenol levels seen in vegetarians. Carbohydrate fermentation interferes with bacterial protein degradation $^{90}$ and would, therefore, reduce the level of tyrosine metabolism in the gut.

Antibiotic treatment is known to change intestinal microflora composition ${ }^{14}$ by suppressing the growth of some strains of bacteria while promoting the growth of others. For example, the administration of antibiotics is a factor responsible for the lower colonization rate of Lactobacillus in infants, ${ }^{91}$ while studies by Snydman and colleagues ${ }^{92}$ have shown the antimicrobial resistance of Bacteroides fragilis. This resistance could lead to disturbances in the intestinal flora, encouraging the overgrowth of these phenol-producing bacteria. Since the sequence in which bacteria populate the colon influences subsequent species' colonization and proliferation, it has been hypothesized that early colonization by Lactobacillus serves as a barrier against potentially pathogenic bacteria. ${ }^{14}$ In the absence of this barrier, other bacteria may flourish.

Interestingly, breastfeeding also serves as another source of Lactobacillus, ${ }^{93}$ which do not produce phenol (Figure 3), and breastfeeding has recently been associated with a reduction in risk of childhood leukemia. ${ }^{15}$ More study into this possible link is needed.

\section{Hydroquinone from arbutin}

Arbutin, a glucose conjugate of hydroquinone (4-hydroxy- D-glucopyranoside), occurs naturally in many plant foods. Arbutin is readily hydrolyzed in the stomach to free hydroquinone, which is extensively absorbed through the gastrointestinal tract. Studies by Deisinger et $a^{/ 61}$ showed that wheat products and pears contain high levels of arbutin while the concentration of free hydroquinone is quite low (Table 2). They identified the highest levels of total hydroquinone in wheat germ (10.65 p.p.m.) and d'Anjou pears (15.1 p.p.m.). While lesser amounts of total hydroquinone are found in beverages such as coffee, tea, and red wine (0.1 to 0.4 p.p.m.), these beverages may contribute significant amounts of hydroquinone to the diet, particularly in those who drink more than one cup ( $200 \mathrm{ml}$ ) per day. Within $2 \mathrm{~h}$ of ingestion, volunteers fed a high arbutin-containing diet (784 to $1279 \mathrm{~g}$ total hydroquinone) exhibited a five-fold elevation in plasma hydroquinone levels, increasing from a mean background level of 0.028 p.p.m. to 0.14 p.p.m. ${ }^{61}$ Likewise, significant increases in urinary hydroquinone levels were observed. Background levels of hydroquinone in the range of 0 to $100 \mathrm{~g} / \mathrm{h}$ surged to $700-1200 \mathrm{~g} / \mathrm{h}$ for up to $6 \mathrm{~h}$ following treatment. ${ }^{61}$ 
Table 2 Total arbutin and free hydroquinone (HQ) in commonly consumed foods and beverages (data from Deisinger et a ${ }^{61}{ }^{61}$ )

\begin{tabular}{lcccc}
\hline Food & $\begin{array}{c}\text { Free } H Q \\
\text { (p.p.m.) }\end{array}$ & $\begin{array}{c}\text { Total arbutin Serving size } \\
\text { and } H Q \\
\text { (p.p.m.) }\end{array}$ & $\begin{array}{c}\text { Average } H Q \\
\text { intake }(g \\
\text { per serving) }\end{array}$ \\
\hline Wheat cereal & $0.02 \pm 0.04$ & $1.0 \pm 0.1$ & 25 & $23-28$ \\
$\begin{array}{l}\text { Whole wheat } \\
\text { bread }\end{array}$ & 0.21 & $2.0 \pm 0.4$ & 12 & $19-29$ \\
Wheat germ & 0.02 & $10.7 \pm 3.6$ & 3 & $21-43$ \\
Pear & & & & \\
$\quad$ Bosc & 0.02 & $3.8 \pm 0.7$ & 180 & $558-810$ \\
$\quad$ d'Anjou & 0.05 & $15.1 \pm 11.7$ & 180 & $612-4824$ \\
Onion & 0.01 & 0.5 & 85 & 42.5 \\
Coffee & $0.22 \pm 0.05$ & $0.3 \pm 0.04$ & 200 & $52-68$ \\
Tea & 0.02 & $0.1 \pm 0.02$ & 200 & $16-24$ \\
Red wine & 0.5 & 0.4 & 180 & 72 \\
\hline
\end{tabular}

\section{Summary of hypothesis}

The studies described above show that high background levels of phenol and hydroquinone are present in the blood of virtually all individuals, but vary widely. The background levels of phenol or hydroquinone stem from direct dietary ingestion, catabolism of tyrosine and other substrates by gut bacteria, ingestion of arbutin-containing foods, cigarette smoking, use of some medicines, and environmental exposures to benzene (Figure 4). Once inside the body, phenol is converted to hydroquinone, primarily in the liver. Phenol, hydroquinone and other phenolic species are transported via the blood to distant tissues including the bone marrow (Figure 4). Extensive investigations into the mechanism(s) of leukemogenesis of benzene indicate that hydroquinone, or hydroquinone in combination with phenol or other related phenolic metabolites, are probably involved in cancer induction and progression. Indeed, hydroquinone and the other phenolic metabolites of benzene are associated with DNA adducts, oxi-


Figure 4 Overview of the proposed model. dative DNA damage, aneuploidy, chromosomal rearrangements, topoisomerase II inhibition, mitotic spindle disruption, altered hematopoiesis and clonal selection. Thus, our hypothesis, which synthesizes all these observations, is that background levels of phenol and hydroquinone are contributing factors to the development of some forms of leukemia in adults and children. An overview is presented in Figure 4.

\section{Predictions and critiques of the hypothesis}

If this model (Figure 4) is true, then several predictions can be made. For example, background rates of some forms of leukemia should correlate with mean phenol and hydroquinone levels in different populations. Such associations, however, may be overshadowed by genetic and environmental differences among the groups. The model predicts that high protein intake will be a risk factor for leukemia, an association that has been reported in some studies. ${ }^{10,11}$ High protein intake increases the proportion of tyrosine and phenylalanine relative to low-protein diets, and also changes the composition of the gut flora towards more phenol-producing strains. Additional studies are needed to test this association and to determine if conversion of protein to phenol by the gut is an important factor.

Our hypothesis predicts a wide inter-individual variability in leukemia susceptibility among individuals because of widely differing gut flora composition, genetics, medicine and tobacco use and, of course, large variations in diet. This may explain why susceptibility to de novo leukemia has been so difficult to explain in persons without any obvious exposures to leukemogenic agents, such as benzene and ionizing radiation. Specific predictions of our hypothesis include: (1) a high intake of arbutin from the diet and the use of certain medicines will be risk factors for developing leukemia; (2) inflammatory bowel disease will be a risk factor in leukemia; and (3) null or low NQO1 activity or high myeloperoxidase activity will be risk factors.

Probably the strongest argument against our hypothesis is that phenol and hydroquinone are not identified as carcinogens. ${ }^{94,95}$ Recently, the International Agency for Research on Cancer (IARC) evaluated the animal and human evidence for carcinogenicity, and in both cases concluded that phenol or hydroquinone was 'not classifiable as to its carcinogenicity to humans (group 3)'.94 In the case of phenol, the IARC concluded that there was inadequate evidence in animals and in humans. ${ }^{94}$ Of the available studies of phenol-exposed workers, all were accompanied by co-exposures to carcinogens. Phenol has been tested in one study of male and female rats and mice. An increased incidence of leukemia was reported in male rats treated with the lower dose, but not in the highdose male rats, in mice or female rats. Phenol acted as a tumor promoter in tumor initiation-promotion studies using mouse skin. In the case of hydroquinone, the IARC concluded that there was inadequate evidence in humans and limited evidence in animals for carcinogenicity. Several studies of photographic processing involving hydroquinone exposure have been reported. The IARC ${ }^{94}$ felt that only one of these studies provided enough information to demonstrate exposure. In that study a statistically significant increased incidence of malignant melanoma was reported. Hydroquinone has been tested for carcinogenicity in two studies of rats and mice, inducing benign liver tumors in female mice of one study and male mice in another, benign kidney tumors in the male rats of both studies, and mononuclear cell leukemia in female rats of one study. The ability to detect cancer associations with hydro- 
quinone may be difficult given the high background variation and intake from other sources. As described above, co-administration of phenol and hydroquinone reproduce many of the toxic effects observed following exposure to benzene. It may be that the redox cycling and synergistic effects associated with co-exposure are involved in leukemogenesis. No animal cancer study has co-administered phenol and hydroquinone.

Studies have suggested that phenol and hydroquinone, either ingested or formed via the gut flora, will be rapidly conjugated and excreted, more so than phenol and hydroquinone formed from metabolism of benzene. ${ }^{96}$ This phenomenon is due to zonal distribution of conjugating enzymes within the liver. ${ }^{96}$ This fact may relate to the lack of clear associations between cancer induction and exposure to phenol or hydroquinone in humans or animals. It is true that phenol and hydroquinone are efficiently conjugated in the gut and liver by sulfotransferases, glutathione transferases and glucuronyl transferases. However, the observations of blood levels of free phenol and hydroquinone, ${ }^{59,61}$ and high levels of macromolecular adducts of benzoquinone (oxidized hydroquinone) in the blood of humans ${ }^{66}$ and blood and bone marrow of rodents ${ }^{65,68}$ clearly indicate that a significant portion of ingested hydroquinone evades conjugation and is transported to distant tissues and is available for binding. Sulfatases, which cleave phenol and hydroquinone conjugates, may play a role in phenol and hydroquinone availability. ${ }^{17}$

A separate criticism is that we do not know for sure the carcinogenic mechanism of benzene and whether phenol and hydroquinone truly are the primary reactive metabolites. If there were a significant change in our understanding of the carcinogenic mechanism(s) of action for benzene, then our hypothesis would become invalid. As reviewed above, there is a large body of evidence to support the prevailing theory that phenol and hydroquinone are critical players in benzeneinduced leukemia. However, other possible mechanisms have been proposed. For example, benzene oxide, a reactive species and the first oxidation product of benzene (Figure 1), has been recently shown to be somewhat stable in blood (half-life of $8 \mathrm{~min}) .{ }^{97}$ Moreover, benzene oxide adducts with proteins have been measured in rat and mouse bone marrow following administration of benzene. ${ }^{68}$ The relative importance of benzene oxide to other metabolites is not known at this time. Also, other researchers have suggested that open-ring metabolites such as trans, trans-muconaldehyde may also play a role in benzene-induced hematotoxicity (reviewed in Ref. 98). The relative importance of these metabolites is believed to be small, but there is some uncertainty on this point.

A significant drawback of the hypothesis is that it will be very difficult to test. We have noted in previous publications ${ }^{4,6,36}$ that there is wide inter-individual variability in susceptibility to hydroquinone-mediated hematotoxicity (eg from benzene exposure). This variability comes from genetic polymorphisms and differences in activity of key metabolizing enzymes (eg CYP2E1, NQO1 and myeloperoxidase), coexposures and other host factors. In this paper, we further describe the potential for significant variability in the background levels of phenol, hydroquinone and other phenolic species. This variability stems from differences in dietary and medicinal intake, gut flora composition and chemistry, smoking and health status, and environmental exposures. Thus taken together, the numerous sources of variability in quinone-mediated hematotoxicity may reduce the power of a study's ability to detect an association. Use of genetically homogeneous test animals may offer a solution; however, there currently does not exist a good animal model for benzene-

induced (ie quinone-mediated) leukemia.

An attractive feature of our hypothesis is that it may explain why many people who have no known occupational exposures or significant smoking history develop leukemia. The hypothesis predicts that susceptibility to the disease would be related to diet, medicinal intake, genetics and gutflora composition. The latter two of these are largely beyond our control, and thus dietary modification and reduced use of medicines that elevate phenol levels may be the best intervention strategies for lowering leukemia risk.

\section{Acknowledgements}

This work was supported by the California Environmental Protection Agency, the National Institute of Environmental Health Sciences (grants P42ES04705 and R01ES06721) and the National Foundation for Cancer Research. We thank Dr John Curry for his assistance with figure preparation and Dr Bruce Ames for his interest and support of this research.

\section{References}

1 Reis LAG, Kosary CL, Hankey BF, Miller BA, Harras A, Edwards BK. SEER Cancer Statistics Review, 1973-1994. National Cancer Institute: Bethesda, 1997, 97-2789.

2 Sandler DP, Ross JA. Epidemiology of acute leukemia in children and adults. Semin Oncol 1997; 24: 3-16.

3 Doll R, Peto R. The causes of cancer: quantitative estimates of avoidable risks of cancer in the United States today. J Natl Cancer Inst 1981; 66: 1191-1308.

4 Smith MT. The mechanism of benzene-induced leukemia: a hypothesis and speculations on the causes of leukemia. Environ Health Perspect 1996; 104 (Suppl. 6): 1219-1225.

5 Ross D. Metabolic basis of benzene toxicity. Eur J Haematol Suppl 1996; 60: 111-118.

6 Rothman N, Smith MT, Hayes RB, Traver RD, Hoener B-A, Campleman S, Li G-L, Dosemeci M, Linet M, Zhang L, Xi L, Wacholder S, Lu W, Meyer KB, Titenko-Holland N, Stewart JT, Yin S, Ross D. Benzene poisoning, a risk factor for hematological malignancy, is associated with the NQO1 ${ }^{609} \mathrm{C}$ forward T mutation and rapid fractional excretion of chlorzoxazone. Cancer Res 1997; 57: 2839-2842.

7 Larson RA, Wang Y, Banerjee M, Wiemels J, Hartford C, Le Beau $\mathrm{MM}$, Smith MT. Prevalence of the inactivating ${ }^{609} \mathrm{C} \quad \mathrm{T}$ polymorphism in the $\mathrm{NAD}(\mathrm{P}) \mathrm{H}$ :quinone oxidoreductase (NQO1) gene in patients with primary and therapy-related myeloid leukemia. Blood 1999; 94: 803-807.

8 Wiemels JL, Pagnamenta A, Taylor GM, Eden OB, Alexander FE, Greaves MF. A lack of a functional NAD(P)H: quinone oxidoreductase allele is selectively associated with pediatric leukemias that have MLL fusions. Cancer Res 1999; 59: 4095-4099.

9 Wang Y, Morgan G, Wiemels JL, Kane E, Roman E, Cartwright R, Smith MT. The NAD(P)H:quinone oxidoreductase (NQO1) C609T inactivating polymorphism is associated with adult leukemia. Blood 1999; 94 (10 Suppl. 1 Part 1): 76a (Abstr.).

10 Hursting SD, Margolin BH, Switzer BR. Diet and human leukemia: an analysis of international data. Prev Med 1993; 22: 409-422.

11 Peters JM, Preston-Martin S, London SJ, Bowman JD, Buckley JD, Thomas DC. Processed meats and risk of childhood leukemia (California, USA). Cancer Causes Control 1994; 5: 195-202.

12 McKinney PA, Juszczak E, Findlay E, Smith K, Thomson CS. Preand perinatal risk factors for childhood leukaemia and other malignancies: a Scottish case control study. Br J Cancer 1999; 80 : 1844-1851.

13 Sepp E, Julge K, Vasar M, Naaber P, Bjorksten B, Mikelsaar M. Intestinal microflora of Estonian and Swedish infants. Acta Paediatrica 1997; 86: 956-961.

14 Bennet R, Eriksson M, Tafari N, Nord CE. Intestinal Bacteria of 
newborn Ethiopian infants in relation to antibiotic treatment and colonisation by potentially pathogenic gram-negative bacteria. Scan J Infect Dis 1991; 23: 63-69.

15 Shu XO, Linet MS, Steinbuch M, Wen WQ, Buckley JD, Neglia JP, Potter JD, Reaman GH, Robison LL. Breast-feeding and risk of childhood acute leukemia. J Natl Cancer Inst 1999; 91: 1765-1772.

16 Adlerberth I, Carlsson B, de Man P, Jalil F, Khan SR, Larsson P, Mellander L, Svanborg C, Wold AE, Hanson LA. Intestinal colonization with Enterobacteriaceae in Pakistani and Swedish hospitaldelivered infants. Acta Paediatr Scand 1991; 80: 602-610.

17 Low LK, Lambert CE, Meeks JR, Naro PA, Mackerer CR. Tissuespecific metabolism of benzene in Zymbal gland and other solid tumor target tissues in rats. J Am Coll Toxicol 1995; 14: 40-60.

18 Twerdok LE, Trush MA. Differences in quinone reductase activity in primary bone marrow stromal cells derived from $\mathrm{C} 57 \mathrm{BL} / 6$ and DBA/2 mice. Res Commun Chem Pathol Pharmacol 1990; 67: $375-386$.

19 Twerdok LE, Trush MA. Studies on biochemical determinants of quinone-induced toxicity in primary murine bone marrow stromal cells. Adv Exp Med Biol 1991; 283: 843-846.

20 Subrahmanyam VV, Ross D, Eastmond DA, Smith MT. Potential role of free radicals in benzene-induced myelotoxicity and leukemia. Free Rad Biol Med 1991; 11: 495-515.

21 Irons RD, Stillman WS. The effects of benzene and other leukaemogenic agents on haematopoietic stem and progenitor cell differentiation. Eur J Haematol 1996; 57 (Suppl. 60): 119-124.

22 Hazel BA, Kalf GF. Induction of granulocytic differentiation in myeloblasts by hydroquinone, a metabolite of benzene, involves the leukotriene D4 receptor. Recept Signal Transduct 1996; 6: $1-12$.

23 Wiemels J, Smith MT. Enhancement of myeloid cell growth by benzene metabolites via the production of active oxygen species. Free Rad Res 1999; 30: 93-103.

24 Eastmond DA, Smith MT, Irons RD. An interaction of benzene metabolites reproduces the myelotoxicity observed with benzene exposure. Toxicol Appl Pharmacol 1987; 91: 85-95.

25 Guy RL, Dimitriadis EA, Hu PD, Cooper KR, Snyder R. Interactive inhibition of erythroid 59Fe utilization by benzene metabolites in female mice. Chem-Bio Interact 1990; 74: 55-62.

26 Chen $H$, Eastmond DA. Synergistic increase in chromosomal breakage within the euchromatin induced by an interaction of the benzene metabolites phenol and hydroquinone in mice. Carcinogenesis (Oxford) 1995; 16: 1963-1969.

27 Felix CA. Secondary leukemias induced by topoisomerase-targeted drugs. Biochim Biophys Acta 1998; 1400: 233-255.

28 Barale R, Marrazzini A, Betti C, Vangelisti V, Loprieno N, Barrai I. Gentoxicity of two metabolites of benzene: phenol and hydroquinone show strong synergistic effects in vivo. Mutat Res 1990; 244: 15-20.

29 Kolachana P, Subrahmanyam VV, Meyer KB, Zhang L, Smith MT. Benzene and its phenolic metabolites produce oxidative DNA damage in HL60 cells in vitro and in the bone marrow in vivo. Cancer Res 1993; 53: 1023-1026.

30 Lévay G, Bodell WJ. Potentiation of DNA adduct formation in HL60 cells by combinations of benzene metabolites. Proc Natl Acad SCi USA 1992; 89: 7105-7109.

31 Wiemels J, Wiencke JK, Varykoni A, Smith MT. Modulation of the toxicity and macromolecular binding of benzene metabolites by $\mathrm{NAD}(\mathrm{P}) \mathrm{H}$ : quinone oxidoreductase in transfected $\mathrm{HL}-60$ cells. Chem Res Toxicol 1999; 12: 467-475.

32 Zhang L, Smith M, Bandy G, Tamaki S, Aj D. Role of quinones, active oxygen species and metals in the genotoxicity of 1,2,4-benzenetriol, a metabolites of benzene. In: Nohl $\mathrm{H}$, Esterbauer $\mathrm{H}$, Rice-Evans C (eds). Free Radicals in the Environment, and Toxicology. Richelieu Press: London, 1994, pp 521-562.

33 DeCaprio AP. The toxicology of hydroquinone - relevance to occupational and environmental exposure. Crit Rev Toxicol 1999; 29: 283-330.

34 Harrison CJ. The management of patients with leukaemia: the role of cytogenetics in this molecular era. Br J Haematol 2000; 108: 19-30.

35 Rowley JD. The role of chromosome translocations in leukemogenesis. Semin Hematol 1999; 36 (4 Suppl. 7): 59-72.

36 Smith MT, Zhang L. Biomarkers of leukemia risk: benzene as a model. Environ Health Perspect 1998; 106 (Suppl. 4): 937-946.
37 Smith MT, Zhang L, Jeng M, Wang Y, Guo W, Duramad P, Hubbard AE, Hofstadler G, Holland NT. Hydroquinone, a benzene metabolite, increases the level of aneusomy of chromosomes 7 and 8 in human CD34-positive blood progenitor cells. Carcinogenesis 2000; 21: 1485-1490.

38 Zhang L, Wang Y, Shang N, Smith MT. Benzene metabolites induce the loss and long arm deletion of chromosomes 5 and 7 in human lymphocytes. Leukemia Res 1998; 22: 105-113.

39 Zhang L, Rothman N, Wang Y, Smith MT. Increased aneusomy and long arm deletion of chromosomes 5 and 7 in the lymphocytes of Chinese workers exposed to benzene. Carcinogenesis 1998; 19: 1955-1961.

40 Bodell WJ, Pathak DN, Lévay G, Ye Q, Pongracz K. Investigation of the DNA adducts formed in B6C3F1 mice treated with benzene: implications for molecular dosimetry. Environ Health Perspect 1996; 104 (Suppl. 6): 1189-1193.

41 Chen H, Eastmond DA. Topoisomerase inhibition by phenolic metabolites: a potential mechanism for benzene's clastogenic effects. Carcinogenesis (Oxford) 1995; 16: 2301-2307.

42 Smith MT, Zhang L, Wang Y, Hayes RB, Li G, Wiemels J, Dosemeci $M$, Titenko-Holland $N$, Xi L, Kolachana P, Yin S, Rothman $\mathrm{N}$. Increased translocations and aneusomy in chromosomes 8 and 21 among workers exposed to benzene. Cancer Res 1998; 58: $2176-2181$

43 Smith MT, Fanning EW. Report on the workshop entitled: 'Modeling Chemically Induced Leukemia - Implications for Benzene Risk Assessment' (Yountville, California, USA, February 11-13, 1996). Leukemia Res 1997; 21: 361-374.

44 MacEachern L, Laskin DL. Bone marrow phagocytes, inflammatory mediators, and benzene toxicity. In: Schook LB, Laskin DL (eds). Xenobiotic Inflammation. Academic Press: San Diego, 1994, pp 149-171.

45 Snyder R, Kalf GF. A perspective on benzene leukemogenesis. Crit Rev Toxicol 1994; 24: 177-209.

46 Walkley JE, Pagnotto LH, Elkins HB. The measurement of phenol in urine as an index of benzene exposure. Am Ind Hyg Assoc 1961; 22: 362-367.

47 Van Haaften AB, Sie ST. The measurement of phenol in urine by gas chromatography as a check on benzene exposure. J Am Ind Hyg Assoc 1965; 26: 52-58.

48 Docter HJ, Zielhuis RL. Phenol excretion as a measure of benzene exposure. Ann Occ Hyg 1967; 10: 317-326.

49 Inoue O, Seiji K, Kasahara M, Nakatsuka H, Watanabe T, Yin SG, Li GL, Cai SX, Jin C, Ikeda M. Determination of catechol and quinol in the urine of workers exposed to benzene. $\mathrm{Br} J$ Ind Med 1988; 45: 487-492.

50 Inoue O, Seiji K, Kasahara M, Nakatsuka H, Watanabe T, Yin SG, Li GL, Jin C, Cai SX, Wang XZ. Quantitative relation of urinary phenol levels to breathzone benzene concentrations: a factory survey. Br J Ind Med 1986; 43: 692-697.

51 Rothman N, Bechtold WE, Yin SN, Dosemeci M, Li GL, Wang YZ, Griffith WC, Smith MT, Hayes RB. Urinary excretion of phenol, catechol, hydroquinone, and muconic acid by workers occupationally exposed to benzene. Occ Environ Med 1998; 55: 705-711.

52 Ong CN, Kok PW, Lee BL, Shi CY, Ong HY, Chia KS, Lee CS, Luo XW. Evaluation of biomarkers for occupational exposure to benzene. Occ Environ Med 1995; 52: 528-533.

53 Lauwreys R. Benzene. In: Alessio L, Berlin A, Roi R, Boni M (eds). Human Biological Monitoring of Industrial Chemical Series. Commission European Communities: Luxembourg, 1983, pp. 2-22.

54 Bone E, Tamm A, Hill M. The production of urinary phenols by gut bacteria and their possible role in the causation of large bowel cancer. Am J Clin Nutr 1976; 29: 1448-1454.

55 Roush G], Ott MG. A study of benzene exposure versus urinary phenol levels. Am Ind Hyg Assoc J 1977; 38: 67-75.

56 Adlkofer F, Scherer G, Conze C, Angerer J, Lehnert G. Significance of exposure to benzene and other toxic compounds through environmental tobacco smoke. J Cancer Res Clin Oncol 1990; 116: 591-598.

57 Bures J, Jergeová Z, Sobotka L, Cervenka B, Malír F, Horácek J, Zadák Z, Komárková O, Fixa B. (Excretion of phenol and p-cresol in the urine in fasting obese individuals and in persons treated with total enteral nutrition.) Casopis Lekaru Ceskych 1990; 129: 1166-1171. 
58 Bures J, Malír F, Sobotka L, Jergeová Z, Zadák Z, Horácek J, Cervenka B, Komárková O. (Urinary excretion of phenol in Crohn disease during total parenteral nutrition.) Casopis Lekaru Ceskych 1990; 129: 123-125.

59 Ling $W H$, Hänninen O. Shifting from a conventional diet to an uncooked vegan diet reversibly alters fecal hydrolytic activities in humans. J Nutr 1992; 122: 924-930.

60 Pekari K, Vainiotalo S, Heikkilä P, Palotie A, Luotamo M, Riihimäki $\mathrm{V}$. Biological monitoring of occupational exposure to low levels of benzene. Scand J Work Environ Health 1992; 18: 317 322.

61 Deisinger PJ, Hill TS, English JC. Human exposure to naturally occurring hydroquinone. J Toxicol Environ Health 1996; 47: 31-46.

62 Smith EA, Macfarlane GT. Enumeration of human colonic bacteria producing phenolic and indolic compounds: effects of $\mathrm{pH}$, carbohydrate availability and retention time on dissimilatory aromatic amino acid metabolism. J App/ Bacteriol 1996; 81: 288-302.

63 Bakke OM. Urinary simple phenols in rats fed diets containing different amounts of casein and 10 per cent tyrosine. J Nutr 1969; 98: 217-221.

64 Bakke OM. Urinary simple phenols in rats fed purified and nonpurified diets. J Nutr 1969; 98: 209-216.

65 Bechtold WE, Strunk MR, Thornton-Manning JR, Henderson R. Polyphenolic metabolites in the blood and bone marrow of mice exposed to low levels of benzene. Abst Papers Am Chem Soc 1996; 212: TOXI 22 (Abstr).

66 McDonald TA, Waidyanatha S, Rappaport SM. Measurement of adducts of benzoquinone with hemoglobin and albumin. Carcinogenesis 1993; 14: 1927-1932.

67 Waidyanatha S, Yeowell-O'Connell K, Rappaport SM. Albumin and hemoglobin adducts of 1,2- and 1,4-benzoquinone in $\left({ }^{14} \mathrm{C} /{ }^{13} \mathrm{C}_{6}\right)$ benzene-dosed rats. Proc Am Assoc Cancer Res Ann Meeting 1998; 39: 333 (Abstr).

68 McDonald TA, Yeowell-O'Connell K, Rappaport SM. Comparison of protein adducts of benzene oxide and benzoquinone in the blood and bone marrow of rats and mice exposed to $\left({ }^{14} \mathrm{C} /{ }^{13} \mathrm{C}_{6}\right)$ benzene. Cancer Res 1994; 54: 4907-4914.

69 Reddy MV, Schultz SC, Blackburn GR, Mackerer CR. Lack of DNA adduct formation in mice treated with benzene. Mutat Res 1994 325: 149-155.

70 Orii S, Sugai T, Nakano O, Yoshinari H, Sato S. Acute promyelocytic leukemia in Crohn's disease. Case report and review of the literature. J Clin Gastroenterol 1991; 13: 325-327.

71 Puig CM, Driscoll CL, Kern EB. Sluder's sphenopalatine ganglion neuralgia - treatment with 88\% phenol. Am J Rhinol 1998; 12 113-118.

72 Guliaev AA, Shapovaliants SG, Burova VA. Obliteration of gallbladder lumen in patients with high operation risk. Khirurgiia 1998; 9: 42-44.

73 Yoon ES, Ahn DS. Report of phenol peel for Asians. Plastic Reconstruct Surg 1999; 103: 207-214.

74 Rahn ML, Lazar LG. Phenol matricectomy in patients with diabetes. J Foot Ankle Surg 1997; 36: 464-465.

75 Fishbeck WA, Langner RR, Kociba RJ. Elevated urinary phenol levels not related to benzene exposure. Am Ind Hyg Assoc J 1975; 36: $820-824$

76 Carmella SG, La Voie EJ, Hecht SS. Quantitative analysis of catechol and 4-methylcatechol in human urine. Food Chem Toxicol 1982; 20: 587-590.

77 Hoffmann D, Wynder EL. Chemical constituents and bioactivity of tobacco smoke. IARC Sci Publ 1986; 314: 145-165.

78 Hawthorne SB, Krieger MS, Miller DJ, Mathiason MB. Collection and quantitation of methoxylated phenol tracers for atmospheric pollution from residential wood stoves. Environ Sci Tech 1989; 23: 470-475

79 Haufroid V, Hotz P, Carbonnelle P, Lauwerys R. Relationships between smoking habits, smoking-associated hematological changes, and urinary benzene metabolites. J Toxicol Environ Health 1997; 52: 1-17.

80 McLaughlin JK, Hrubec Z, Linet MS, Heineman EF, Blot WJ, Fraumeni JF Jr. Cigarette smoking and leukemia. J Natl Cancer Inst 1989; 81: 1262-1263.

81 Garfinkel L, Boffetta P. Association between smoking and leuke- mia in two American Cancer Society prospective studies. Cancer 1990; 65: 2356-2360.

82 Scheline RR. Metabolism of phenolic acids by the rat intestinal microflora. Acta Pharmacol Toxicol (Copenh) 1968; 26: 189-205.

83 Scheline RR. The decarboxylation of some phenolic acids by the rat. Acta Pharmacol Toxicol (Copenh) 1966; 24: 275-285.

84 Draths KM, Frost JW. Conversion of D-glucose into catechol: the not-so-common pathway of aromatic biosynthesis. J Am Chem Soc 1991; 113: 9361-9363.

85 Marteau P, Pochart M, Bouhnik Y, Rambaud JC. The fate and effects of transiting, nonpathogenic microorganisms in the human intestine. World Rev Nutr Diet 1993; 74: 1-21.

86 McBain AJ, Macfarlane GT. Ecological and physiological studies on large intestinal bacteria in relation to production of hydrolytic and reductive enzymes involved in formation of genotoxic metabolites. J Med Microbiol 1998; 47: 407-416.

87 Maier BR, Flynn MA, Burton GC, Tsutakawa RK, Hentges DJ. Effects of a high-beef diet on bowel flora: a preliminary report. Am J Clin Nutr 1974; 27: 1470-1474.

88 Hentges DJ. Does diet influence human fecal microflora composition? Nutr Rev 1980; 38: 329-336.

89 Hill MJ, Drasar BS, Hawksworth G, Aries V, Crowther JS, Williams RE. Bacteria and aetiology of cancer of large bowel. Lancet 1971; 1: 95-100.

90 MacNeil N. Nutritional implications of human and mammalian large intestinal function. World Rev Nutr Diet 1988; 56: 11-42.

91 Hall MA, Cole CB, Smith SL, Fuller R, Rolles CJ. Factors influencing the presence of faecal lactobacilli in early infancy. Arch Dis Child 1990; 65: 185-188.

92 Snydman DR, Jacobus NV, McDermott LA, Supran S, Cuchural GJ, Finegold S, Harrell L, Hecht DW, Iannini P, Jenkins S, Pierson C, Rihs J, Gorbach SL. Multicenter study of in vitro susceptibility of the Bacteroides fragilis group, 1995 to 1996, with comparison of resistance trends from 1990 to 1996. Antimicrobial Agents Chemother 1999; 43: 2417-2422.

93 Orrhage K, Nord CE. Factors controlling the bacterial colonization of the intestine in breastfed infants. Acta Paediatr Suppl 1999; 88: 47-57.

94 International Agency for Research on Cancer (IARC). Re-evaluation of some organic chemicals, hydrazine, and hydrogen peroxide. IARC Monographs on the Evaluation of Carcinogenic Risks to Humans. IARC: Lyon, 1999; 71: 433-452 (catechol), 749-768

95 Office of Environmental Health Hazard Assessment (OEHHA), California Environmental Protection Agency. Chemicals known to the state to cause cancer or reproductive toxicity. Safe Drinking Water and Toxic Enforcement Act of 1986 (Proposition 65), www.oehha.ca.gov/prop65/prop65_list/Newlist.html.

96 Medinsky MA, Kenyon EM, Seaton MJ, Schlosser PM. Mechanistic considerations in benzene physiological model development. Environ Health Perspect 1996; 104 (Suppl. 6): 1399-1404.

97 Lindstrom AB, Yeowell-O'Connell K, Waidyanatha S, McDonald TA, Golding BT, Rappaport SM. Formation of hemoglobin and albumin adducts of benzene oxide in mouse, rat, and human blood. Chem Res Toxicol 1998; 11: 302-310.

98 Witz G, Zhang Z, Goldstein BD. Reactive ring-opened aldehyde metabolites in benzene hematotoxicity. Environ Health Perspect 1996; 104 (Suppl. 6): 1195-1199.

99 International Agency for Research on Cancer (IARC). Coffee, tea, mate, methylxanthines and methylglyoxal. IARC Working Group on the Evaluation of Carcinogenic Risks to Humans. IARC Monographs on the Evaluation of Carcinogenic Risks to Humans. IARC: Lyon, 1991; 51: 1-513.

100 Clark RJ, Macrae R. Coffee Volume 1: Chemistry. Elsevier Applied Science: London, 1985; p 193

101 Rahn W, König A. GC/MS investigations of the constituents in a diethyl ether extract of an acidified roast coffee infusion. J High Resolut Chromatogr Commun 1978; 1: 69-71.

102 Maga JA. Simple phenol and phenolic compounds in food flavor. CRC Crit Rev Food Sci Nutr 1978; 10: 323-327.

103 Diechman WB, Keplinger ML. Phenols and phenolic compounds. In: Clayton GD, Clayton FE (eds). Patty's Industrial Hygiene and Toxicology Volume 2A, 3rd revised edn. John Wiley \& Sons: New York, 1981, pp 2567-2628.

104 Brewington RC, Parks OW, Schwartz DP. Conjugated compounds in cow's milk. II. J Agr Food Chem 1974; 22: 293-294. 
105 Harbison KG, Belly RT. The biodegradation of hydroquinone. Environ Toxicol Chem 1982; 1: 9-15.

106 Takeba K, Matsumoto M, Shida Y, Nakazawa H. Determination of phenol in honey by liquid chromatography with amperometric detection. J Assoc Off Anal Chem 1990; 73: 602-604.

107 Schmidt EG. An ether extraction method for the determination of urine phenols. J Biol Chem 1942; 145: 533-544.

108 Teisinger J, Fiserova-Bergerova V. Valeur comparee de la determination des sulfates et du phenol contenus dans l'urine pour l'evaluation de la concentration du benzene dans I'air. Archs Mal Prof Med Trav 1955; 16: 221-230. 